\title{
Texts about Girls, for Girls and by Girls
}

\author{
Jacqueline Reid-Walsh and Kirstin Bratt
}

\section{$\cos 80$}

Perhaps it is more obvious in the present day, surrounded as we are by cell phones and other electronic devices transmitting information and messages in images and words instantaneously, but for over a hundred years the lives of girls - middle class girls in particular-have been mediated to a large extent by the plethora of texts that surround them. These texts are largely fictional narratives in different formats such as novels, magazines, television shows and films, many of which appear as digital media. Some of these texts are composed by adults, often women, and are directed at girl readers and viewers in an effort to establish a direct or indirect pedagogical relationship with them. Then again, depending often on how fantasy and desire is constructed in the narrative, other texts have no apparent pedagogical function, serving instead as sites (some adult-sanctioned and some not) of escape from reality. Other texts are created by the girls themselves and are directed at members of their own age group either as texts of peer education or of entertainment.

We have divided this issue into two parts: the first consists of articles that deal with novels of one sort or another, and in the second we have placed those that deal with media texts and, in the case of Stephanie Troutman's article, with media literacy/ies. Here, too, appear a visual essay and two book reviews.

In "Doing Her Bit: German and Anglo-American Girls' Literature of the First World War," Jennifer Redmann looks at different works of girls' literature published in Germany, Great Britain, the United States and Canada during or immediately after the First World War. She is interested in what these novels reveal about the gap between girls' expectations and the opportunities available to them at this time. On the one hand, girls were being exhorted to show patriotism in serving their country but, on the other, they were constantly being reminded of the gendered limitations of such service. Redmann recognizes that when 
men were on the battlefield huge numbers of women in the combatant nations took over their jobs, but after the war "many of their positions disappeared or had to be relinquished to returning men. Independent women did move out of the domestic sphere, but the tremendous loss of life in battle led to a renewed societal emphasis on women's traditional roles as mothers and homemakers." Redmann explores how these works written for girls engage with the "theme of maturation [which] is central to girls' literature from the mid-nineteenth century on" and shows how this thematic concern "gains urgency [in these books] in the face of military crisis and conflict" during and after the war.

Then, in “'A Pretty Girl of Sixteen': Capturing the Contradictions of Female Adolescence in the Nancy Drew Series," Kate Harper offers an analysis of how "the development of the concept of adolescence and its gendered implications" for girls is dealt with in The Secret of the Old Clock, The Hidden Staircase, and The Bungalow Mystery, all of which appeared in 1930. She argues that this series of novels for girls refuses and rejects the notion-prevalent in the 1930s — that adolescence is necessarily "a period of turmoil and emotional instability" along with its related "association of female adolescent sexuality with delinquency." In her cogent and carefully contextualized analysis, Harper demonstrates that these three novels in this series did not advocate the necessity of the "constant adult supervision" that goes, inevitably, with such notions. But Harper links this to her investigation of the character of Nancy Drew in its capturing of "the contradictory messages of female adolescence in the 1930s when girls were represented as sexually attractive and aggressive but were denied sexual desire." Because Nancy never engages in any behavior that has even a hint of the sexual, as Harper points out, the absence of parental control in her life "never lead[s] her into delinquency."

Following this, Julianne Guillard analyzes the Twilight series of novels, advertised as gothic, which appeared between 2005 and 2008, in terms of the conventions of the late eighteenth and early nineteenth century genre of the Gothic novel. In "You are exactly my brand of heroin(e)': Convergences and Divergences of the Gothic Literary Heroine," she offers a comparison between Jane Eyre and Bella in which she claims that in the character of Bella her creator, Stephenie Meyer, has constructed "a particular category of contemporary gothic heroine" in a merging of "elements of the bildungsroman and the Female Gothic" so 
as to create her own "brand of heroine." Guillard picks up, wittily and neatly, on Edward's statement to Bella that she is his "brand of heroin" and she plays on this to show how Bella, as though drugged by this, complies with the "brand of heroine [who] fulfills the three distinct categories of girlhood and womanhood" that characterize both the Gothic novel and the bildungsroman: a dependent stage; a caretaker stage; and a wife stage. She explores this notion of a "hybrid heroine" within a "hybrid genre" in a contextualized analysis of different approaches to the Gothic since it is impossible to define given its many subgenres each of which has its own often overlapping "substructures and characterizations." In so doing, Guillard reveals the conventional female heroine within Bella that is seemingly belied by the novel's premise. While the heroine of the Twilight series is presented as modernly unconventional in terms of the stereotypes of what is known as contemporary chick lit, Bella represents, in her view, a return to the conventions of much earlier fiction.

In the last article in this section, Alyson E. King, in "Hating Everything: A Coming-of-age Graphic Narrative," analyzes the Canadian graphic novel Skim by Mariko Tamaki and Jillian Tamaki (2008) which uses "detailed black-and-white drawings and few words" to tell a story set in a girls' high school in the 1990s. King is interested in how "words and images work together to portray the life of a teenage girl" in this graphic novel and her insightful analysis is as much about how we read these works (necessarily, in non-linear ways) as it is about the concerns of this particular novel that was either nominated for, or won, a slew of highly prestigious prizes. That there is a lesbian subtext in this novel, and one between a student and a teacher, to boot, appears not to matter: little critical reference has been made to this. Mariko Tamaki, in an interview with the author and her colleague Janette Hughes, said that for her, this is a coming-out novel but King's analysis reveals that it is more of a coming-of-age narrative in that Tamaki and Tamaki "[explore] more than just sexuality" in their look at teenage girls and their "weekly, even daily, dramas related to mood, friendships, worries, frustrations, fears" and the other pressures that are typically part of their lives. For King, a central issue is that all this is "portrayed here both visually and textually-a combination reflective of new media in which words and images are inseparable" and she demonstrates how this combination speaks to the unconventional ways in which "those with outsider status 
(such as, for example, gay and lesbian young people who are outside of the majority) [can be] imagined" and represented in graphic novels.

In the second section of this issue we invite you to engage with a set of articles that deal with mainstream electronic media, particularly television and film, and with the role of a feminist pedagogical media literacy intervention in schools.

In her article, "Lessons in Liberation: Schooling Girls in Feminism and Femininity in 1970s ABC Afterschool Specials," Kirsten Pike look at how three episodes— "Rookie of the Year" (1973), "My Mom's Having a Baby" (1977), and "What Are Friends For?" (1980)—from ABC Afterschool Specials "targeted girls through images of female progress and independence while simultaneously cautioning them about the dangers of women's liberation." She establishes telling connections between the taming of tomboys and the backlash that followed the women's and gay liberation movements, and links this neatly to an analysis of "Rookie of the Year" in which gender politics inform the story of a girl who wants to play baseball on an all-boys team in her neighborhood. Then coming from a different angle, she goes on to show how the " $t]$ ensions between feminism and femininity" are played out in "My Mom's Having a Baby" as she demonstrates "that while women's bodies may be amazing, their functions are best explained and controlled by white men" and concludes that "the episode makes it perfectly clear who the real heroes are" in this story about the wonders of the female body. Pike's analysis of the episode "What Are Friends For?" makes clear that a lesbian subtext seems to have been included only to provide a reason for censure. On a hopeful note, though, she concludes that although the $A B C$ Specials were "decidedly less progressive than what their critical accolades might suggest," some of the episodes did at least extend the possibilities available to female youth. She finds it likely that "some girls took away from Specials a sense of feminist awareness, feminist inspiration, and/or the seeds for developing future feminist politics."

Katherine Allocco, in her article, "Putting the Grail Back into Girl Power: How a Girl Saved Camelot, and Why It Matters," explores the character of Kayley as depicted in the Warner Bros animated film Quest for Camelot (1998) which is set in the time of King Arthur. She suggests that Kayley's feminism is presented as a matter-of-fact part of her existence and is offered to the viewer "without apology or self-congratulation." Kayley has no need to act in traditionally masculine ways and it 
is this refusal of the "expectations of stereotyped gendered behavior" behind her creation by the screen writers, including Jacqueline Feather, that sets this film apart from many others based on similar times and themes. In a very useful and enlightening comparison between Kayley and the eponymous Mulan in the Walt Disney Feature Animation film of the same year, Allocco reinforces her point that a girl in a film, and by extension of course, in real life, can be heroic without allowing the constraints inherent in enacting behavior based on "narrowly defining a hero as an aggressive warrior" to hold her back. In addition, Kayley's life is not filled with "the sexual pressures that complicate" the life of Buffy the Vampire Slayer, for example. Allocco juxtaposes all this against the problematic aspects of the otherwise empowering Girl Power movement in relation to the real lived gender politics of girls who, with "their well-groomed bodies and skimpy costumes were hyperfeminized and supersexualized" in various media representations.

In her article, "Analog Girls in a Digital World? Instructional Practice through Feminist Pedagogical Media Literacy," Stephanie Troutman, suggests that the advancement of the "multi-faceted media and new literacies form" she calls "feminist pedagogical media literacy (FPML)" would be "a mode of empowerment for girls and young women" in the classroom particularly in this "heavily mediated [and] globally saturated cultural moment." Troutman brings together, though not always in favour of the former, feminist pedagogy and FPML to show how, in spite of her concerns, they can be yoked together in the service of improved media literacy. Troutman is concerned to show that while FPML can serve to help girls and women to deconstruct the images of themselves as females with which they are faced in the world it can also serve "to strategically advance and promote the dialogue on females as producers." Troutman's focus is on teenage girls not only because they under-participate in some new media forms but also because of "the representational binary in which they tend to be positioned: objectified and passive, or empowered by and through sexuality." She sees this FPML intervention as essential because for her, as for Greg Dimitriadis (2001), "education today is an emergent and unfinished idea" (17). Girls must be armed, as it were, to deal with the stereotypical expectations of them as females and this might well be the best way of doing this. In addition to mitigating the effects of these stereotypical expectations, feminist pedagogical media literacy will give them ways "to create 
alternative and even hybrid artifacts that speak to the complications and contradictions therein, without forcing them to altogether reject such constructions."

Juxtaposed against these analyses of texts directed toward girls, the visual essay in this issue "Girls use Digital Photography to Speak Out about Sexuality and HIV," by Katie MacEntee, Lukas Labacher, and John Murray, considers images-as-texts produced by girls and young women who attended the eighteenth International AIDS Conference in Vienna, in July 2010. It demonstrates how a media project involving youth can interrogate an adult-centered event. As part of an "interactive photo project" at the YAHAnet (Youth, the Arts, HIV \& AIDS Network) which is "an online global network and resource center for arts-based activism" which focuses on sexual health and related rights, participants were invited to photograph hands-theirs and/or those of friends - and to add a written message to the printed out photos in response to the theme: "Rights to Expression around Sexuality and HIV and AIDS." The authors offer an "analysis of the photographic messages...produced by girls aged nineteen and younger" and they read the images alongside the grim reality of the statistics relating to the high incidence of HIV infection amongst girls and young women, and the discourse of the conference itself which seemed not to take into consideration the voices of young people.

Picking up on the thread of girls' fiction in the first half of this issue, Elaine J. O'Quinn, in an aptly named review_- "Young Adult Writers, Girls, Body Image and Female Sexuality"-discusses Beth Younger's Learning Curves: Body Image and Female Sexuality in Young Adult Literature. She points out that Younger's concern is to "show how girls navigate and negotiate the contradictions of growing up through the lives of the characters" that appear in the books they read. These readers engage with characters who deal with the same complications as those with which they live. This vicarious existence, as it were, in the world of a novel gives readers an understanding of various issues as well as possible ways of dealing with them in the real world. For example, although (or perhaps because) "teen pregnancy is seen to be socially unacceptable," Younger offers details about books that "provide information about prenatal care and birth control" rather than offering only censure and threat of punishment. Interestingly, given some of the issues explored in this issue, O'Quinn draws attention to Younger's 
observation that those who challenge teenage pregnancy stereotypes include writers like "Norma Klein and Marilyn Reynolds who were writing for a previous generation.” O'Quinn alerts us, too, to the way in which "Younger's book provides much to think about and consider in both our historical look back at books for girls as well as in our consideration of what might be expected of more modern titles."

Finally, Eluned Jones's passionate and detailed review, "Learning the Ropes from Black Girls," of Kyra D. Gaunt's The Games Black Girls Play: Learning the Ropes from Double-Dutch to Hip-Hop serves to sum up a number of the concerns of this issue. She points out that Black girls are regularly stereotyped as sexually precocious beings-reminding us as she does so that the title of this book recalls these stereotypes in its reference to the "games black girls play" and tells us that in Gaunt's book these girls are "defiantly returned to the realm of childhood play." Jones's analysis of the relationship between the structure of the book and Gaunt's walking the tightrope of academia in it is telling. She notes that Gaunt moves from dry theory at the start of the work to exuberant delight as she learns how to dance "between the ropes supported and celebrated by her sistahs."

In this issue on texts and texuality we return explicitly to the central concern of Girlhood Studies which is that our focus should be on issues about girls, for girls and by girls, and here we take into account, in particular, the mediated domains in which and through which these texts operate. 